\title{
Improvement of the detection limit by radon background reduction method
}

- Tran Thien Thanh

- Chau Van Tao

University of Science, VNU-HCM

- Laurent Ferreux

- Marie Christine Lépy

CEA, LIST, Laboratoire National Henri Becquerel (LNE-LNHB)

(Received on $3^{\text {rd }}$ March 2016, accepted on $2^{\text {th }}$ December 2016)

\section{ABSTRACT}

This paper describes a simple method to reduce the radon background component applied in environmental studies using gamma spectrometry. The radon component can be reduced by introducing either nitrogen gas or clean air into the detector chamber in order to create a positive pressure and further minimize

radon intrusion from outside. This method shows that we can minimize the influence of radon daughter background such as ${ }^{214} \mathrm{~Pb},{ }^{214} \mathrm{Bi}$ and ${ }^{210} \mathrm{~Pb}$ (from ${ }^{238} \mathrm{U}$ ), ${ }^{212} \mathrm{~Pb},{ }^{212} \mathrm{Bi}$ and ${ }^{208} \mathrm{Tl}$ (from $\left.{ }^{232} \mathrm{Th}\right)$. By the way, the detection limit of the gamma spectrometry is discussed.

Keywords: gamma spectrometry, limit detection, background

\section{INTRODUCTION}

There are many efforts to the issues such as to look for the proper shielding materials for better detector housing and so on. Techniques developed so far for rare event research, dark matter search in particle and nuclear physics research are well known. In this research we would like to investigate the most suitable and sensitive technique for fixing the background origin in the materials.

To improve the detection limits in low level activity measurements, the background has to be reduced as much as possible. The background spectrum of a germanium detector is due to a combination of different components such as environmental gamma radiation, radioactivity in the construction material of the detector, radio impurities in the shield, cosmic rays and radon gas. The first three contributions can be reduced drastically by means of a suitable passive shielding made of old or very low - activity lead and by a careful selection of materials surrounding the crystal. The cosmic ray component has been reduced by installing the germanium detector in an underground laboratory. However, building and operating an underground laboratory is expensive and inconvenient. Another possibility is to operate a gamma-ray spectrometer with an anticoincidence system i.e. a plastic scintillator surrounding the lead shield in anticoincidence with the germanium detector as active shielding [2].

Radon isotopes, both radon, ${ }^{222} \mathrm{Rn}$, and thoron, ${ }^{220} \mathrm{Rn}$, are present in air as active gases emanating from traces of ${ }^{238} \mathrm{U}$ and ${ }^{232} \mathrm{Th}$ in building constructional materials and/or local soils and rock. They can be absorbed on dust particles and surfaces within the detector enclosure and give rise to characteristic peaks of ${ }^{214} \mathrm{~Pb},{ }^{214} \mathrm{Bi}$ and ${ }^{210} \mathrm{~Pb}$, (in the ${ }^{238} \mathrm{U}$ series) and ${ }^{212} \mathrm{~Pb},{ }^{212} \mathrm{Bi}$ and ${ }^{208} \mathrm{Tl}$ (in the ${ }^{232} \mathrm{Th}$ series) in the background. The difficulty with radon is that its concentration around the detector is likely to vary

\section{Trang 126}


with time of day and season of the year, and with atmospheric pressure, wind speed, temperature, etc. A reliable and reproducible background from radon daughters is often difficult to achieve $[1,3$ $6]$.

In this work, we measure and evaluate reduced radon daughter into background spectra with and without vent gas from the liquid nitrogen Dewar into the shielding and calculate the limit of detection of gamma spectrometry using HPGe detector.

\section{MATERIALS AND METHOD}

\section{Detector}

The experimental set-up is a low-level gamma spectrometer including an HPGe detector with conventional amplifying and coding systems. This is equipped with an active shielding consisting in plastic scintillators working in anti-coincidence mode. The HPGe detector includes the germanium crystal cylinder with $66 \mathrm{~mm}$ outer diameter and $64 \mathrm{~mm}$ height. Inside the crystal, and there is a hole with $15 \mathrm{~mm}$ diameter, $51 \mathrm{~mm}$ depth and the relative efficiency of $51.6 \%$. Furthermore, there is an outer lithium layer, and an inner boron layer of the crystal. Acquisitions with detector are driven using InterWinner software that is also used for spectra display and processing.

The detector is included in a cylindrical measurement chamber $(\phi=80 \mathrm{~mm}, \mathrm{H}=400 \mathrm{~mm})$ made of $4 \mathrm{~mm}$ selected copper with a parallel epiped shielding successively composed of a $50 \mathrm{~mm}$-thick very low activity lead $\left(\mathrm{A}<10 \mathrm{~Bq} \cdot \mathrm{kg}^{-1}\right)$, a $3 \mathrm{~mm}$ thick selected cadmium $\left(\mathrm{A}<50 \mathrm{~Bq} \cdot \mathrm{kg}^{-1}\right)$ and a $100 \mathrm{~mm}$ thick low activity lead $\left(\mathrm{A}<50 \mathrm{~Bq} \cdot \mathrm{kg}^{-1}\right)$. The material composition of the bottom is the same except the thickness of the low activity lead is $150 \mathrm{~mm}$. The measurement chamber is filled with nitrogen gas exiting from the cooling Dewar to remove the radon from the chamber (Fig. 1). Finally, the whole system is installed in an underground laboratory isolated with $1.50 \mathrm{~m}$ concrete walls and $1 \mathrm{~m}$ underground. This room is also equipped with specific ventilation and air conditioning system with double dust filtering, thus insuring air regeneration 7 times per day. The active shielding is performed using 5 plastic scintillators with the dimension of $750 \times 750 \times 70 \mathrm{~mm}^{3}$. They are out one at the top, four at the four edges and nothing at the botton [1].

\section{Standard solutions}

The efficiency curve was obtained using the so-called "SG50" volume geometry $50 \mathrm{~cm}^{3}$; and the container has the following characteristics: external diameter $40 \mathrm{~mm}$, wall thickness $1.2 \mathrm{~mm}$, bottom thickness $1.4 \mathrm{~mm}$ and the liquid is filled to the height of $4.56 \mathrm{~mm}$. The initial efficiency curve was established in 2003, using nuclides such as ${ }^{210} \mathrm{~Pb},{ }^{241} \mathrm{Am},{ }^{109} \mathrm{Cd},{ }^{57} \mathrm{Co},{ }^{139} \mathrm{Ce},{ }^{51} \mathrm{Cr}$, ${ }^{113} \mathrm{Sn},{ }^{85} \mathrm{Sr},{ }^{137} \mathrm{Cs},{ }^{65} \mathrm{Zn},{ }^{22} \mathrm{Na},{ }^{60} \mathrm{Co},{ }^{40} \mathrm{~K}$ and ${ }^{88} \mathrm{Y}$. A general efficiency curve (efficiency versus energy) was obtained by fitting a $\log \log$ polynomial to experimental values obtained by using the liquid standard sources.

The resulted validation efficiency is presented in Fig. 1. This indicates that the established efficiency curve is adequate to calculate the activity concentrations of the sediment marine sample.

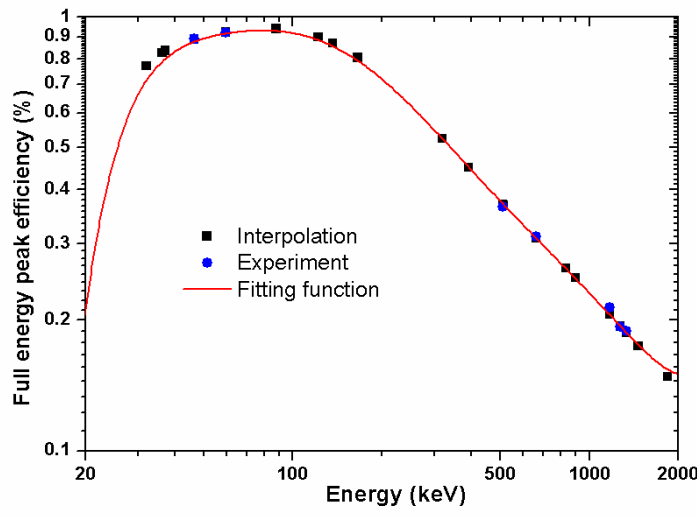

Fig. 1. Validation efficiency curve of SG50 geometry at $10 \mathrm{~cm}$

Trang 127 


\section{RESULTS AND DISCUSSION}

The effect of the radon suppression is shown in Table 1. Some reduction is observed in the gamma ray peaks of the ${ }^{222} \mathrm{Rn}$ progenies, ${ }^{214} \mathrm{~Pb}$ and ${ }^{214} \mathrm{Bi}$ are by factors of 3.2-5.1 for ${ }^{214} \mathrm{~Pb}$ and 5.6-6.3 for ${ }^{214} \mathrm{Bi}$. Besides, ${ }^{220} \mathrm{Rn}$ daughter, the count rate in ${ }^{212} \mathrm{~Pb}$ is reduced 1.8 and 1.2 for ${ }^{208} \mathrm{Tl}$.

Table 1. Comparison count rates minute peak (c.p.m) for with and without nitrogen

\begin{tabular}{|c|c|c|c|c|}
\hline Radionuclides & $\begin{array}{c}\text { Energy } \\
(\mathrm{keV})\end{array}$ & $\begin{array}{c}\text { With nitrogen } \\
\text { (W) (c.p.m) }\end{array}$ & $\begin{array}{c}\text { Without nitrogen } \\
\text { (Wo) (c.p.m) }\end{array}$ & $\begin{array}{c}\text { Ratio } \\
\text { Wo/W }\end{array}$ \\
\hline${ }^{210} \mathrm{~Pb}$ & 46.5 & $0.367(7)$ & $0.382(7)$ & 1.0 \\
\hline${ }^{226} \mathrm{Ra}$ & 186.2 & $0.166(4)$ & $0.196(5)$ & 1.2 \\
\hline${ }^{212} \mathrm{~Pb}$ & 238.6 & $0.125(4)$ & $0.224(5)$ & 1.8 \\
\hline${ }^{214} \mathrm{~Pb}$ & 295.2 & $0.087(3)$ & $0.283(6)$ & 3.2 \\
\hline${ }^{214} \mathrm{~Pb}$ & 351.9 & $0.078(3)$ & $0.395(7)$ & 5.1 \\
\hline${ }^{214} \mathrm{Bi}$ & 609.3 & $0.042(2)$ & $0.264(6)$ & 6.3 \\
\hline${ }^{214} \mathrm{Bi}$ & 1764.5 & $0.008(1)$ & $0.045(2)$ & 5.6 \\
\hline${ }^{208} \mathrm{Tl}$ & 2614.5 & $0.009(1)$ & $0.010(1)$ & 1.2 \\
\hline
\end{tabular}

$0.367(7)=0.367 \pm 0.007$

Fig. 2A and 2B presented the measurement results with acquisition time 504000s with and without nitrogen, respectively.
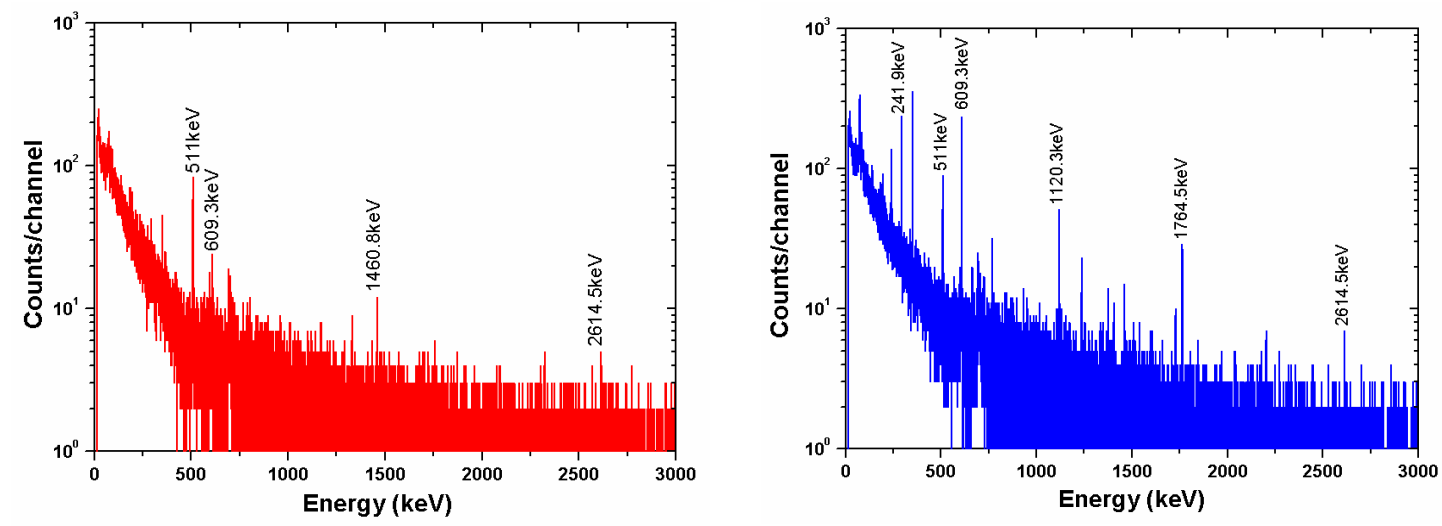

Fig. 2. A. The spectrum with nitrogen; B. The spectrum without nitrogen

However, several applications of environmental radioactivity require not only low background but also lower limit of detection $\left(\mathrm{L}_{\mathrm{D}}\right)$ for different samples. It has been obtained according to the equation [2]:

$$
\mathrm{L}_{\mathrm{D}}=2.71+3.29 \sqrt{\mathrm{B}}
$$

where $\mathrm{B}$ is the integral background in the region of interest (counts), $\mathrm{n}$ is the number of channels in the peak region of interest, $\mathrm{m}$ is the number of background channels on each side of the peak.

The minimum detectable activity (MDA) was calculated:

$$
\mathrm{MDA}=\frac{\mathrm{L}_{\mathrm{D}}}{\varepsilon . \mathrm{I}_{\gamma} \mathrm{t.} . \mathrm{V}}
$$

where $\varepsilon$ is the detection efficiency of the peak, $\quad I \gamma$ is the gamma ray emission probability and $t$ is the acquisition time(s) and

\section{Trang 128}


$\mathrm{V}$ is the sample volume or mass. In Eq. (2), the confidence level is $95 \%$.

On the other hand, the MDA is calculated for HPGe detector for a SG50 geometry as given in the formula 2. The MDA is clearly improved (see Fig. 3) using radon suppression system for the ${ }^{222} \mathrm{Rn}$ progenies and the ${ }^{220} \mathrm{Rn}$ daughter.

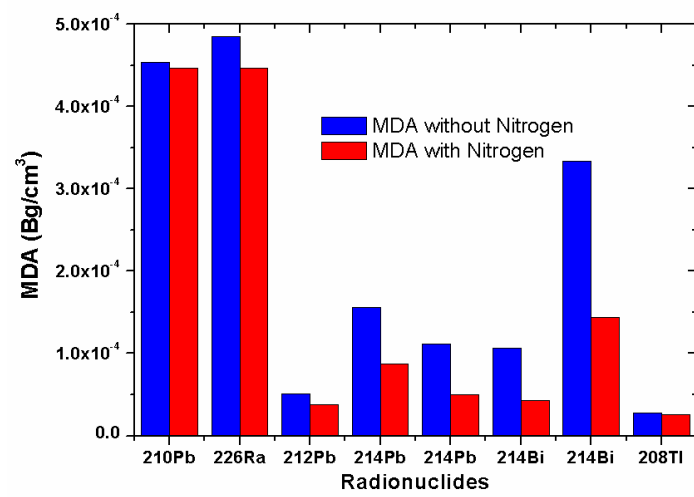

Fig. 3. Comparison of MDA values for SG50 geometry with and without nitrogen in shielding

Because, 'environmental' origin soils, waters and such like are measured either to determine background levels of radiation or to assess the level of contamination as a consequence of human activity. The nuclides usually measured by gamma spectrometry are the cosmogenic nuclides: ${ }^{40} \mathrm{~K},{ }^{235} \mathrm{U},{ }^{238} \mathrm{U}$ and ${ }^{232} \mathrm{Th}$. In many cases, it will be necessary to make a peaked background correction in addition to the normal peak background continuum subtraction. All of those difficulties are then compounded by the fact that there are a large number of mutual spectral interferences between many nuclides in the decay series of uranium and thorium.

\section{CONCLUSION}

This study shows that with and without nitrogen gas, is necessary to reduce the radon background. This method can use the gamma spectrometry to calculate the radioactivity of the environmental sample.

Acknowledgments: The first author would like to thank the French Atomic Energy Commission (CEA) and the French Metrology Institute (Laboratoire National de métrologie et d'Essais- LNE) for the financial supporting this work.

\section{Cải tiến giới hạn phát hiện bằng phương pháp giảm phông radon}

\section{- Trần Thiện Thanh}

- Châu Văn Tạo

Trường Đại học Khoa học Tự nhiên, ĐHQG-HCM

- Laurent Ferreux

- Marie Christine Lépy

CEA, LIST, Phòng Thí nghiệm Quốc gia Henri Becquerel (LNE-LNHB)

\section{TÓM TẮT}

Bài báo trình bày một phuoong pháp đơn giản để giảm thành phần phông radon ưng dụng cho hẹ phổ kế gamma trong nghiên cưu môi truờng. Thành phần khí radon đuợc giảm bằng cách sủ dụng khi nitrogen tù bình làm lạnh hoạc khi sạch tù bên ngoài để tạo ra một áp suất duong bên

trong buồng đo và thêm vào đó là giảm luợng khí radon tù bên ngoài. Phuoong pháp này chỉ ra rằng có thể giảm thiểu ảnh hưởng phông tù con cháu radon $n h u{ }^{214} \mathrm{~Pb},{ }^{214} \mathrm{Bi}$ vă ${ }^{210} \mathrm{~Pb}$ (tìu $\left.{ }^{238} \mathrm{U}\right),{ }^{212} \mathrm{~Pb}$, ${ }^{212} \mathrm{Bi}$ và ${ }^{208} \mathrm{Tl}$ (tù̀ ${ }^{232} \mathrm{Th}$ ). Giới hạn phát hiện của phổ kế gamma được thảo luận.

Tù khóa: Radon, phổ kế gamma, giới hạn phát hiện, phông 


\section{REFERENCES}

[1]. L. Ferreux, G. Moutard, T.T. Branger, Measurement of natural radionuclides in phosphgypsum using an anti-cosmic gamma-ray spectrometer, Appl. Radiat. Isot 67, 957-960 (2009).

[2]. G. Gilmore, Practical gamma-ray spectrometry 2nd edition, John Wiley \& Son, Ltd (2008).

[3]. M. Hult, Low-level gamma-ray spectrometry using Ge-detectors, Metrologia, 44, S87-S94 (2007).

[4]. S. Hurtado, M. Garcia-Leon, R. GarciaTenorio, Optimized background reduction in low-level gamma-ray spectrometry at a surface laborator, Appl. Radiat. Isot., 64, 1006-1012 (2006).

[5]. T.T. Thanh, L. Ferreux, M.C. Lépy, C.V. Tao, Determination activity of radionuclides in marine sediment by gamma spectrometer with anti cosmic shielding, J. Environ. Radioactiv., 101, 9, 780-783 (2010).

[6]. T.T. Thanh, T.T.H. Loan, M.V. Nhon, C.V. Tao, Improvement passive shielding to background reduction: application to determinate radioactivity at low-energy gamma rays, Kerntechnik, 79, 3, 247-252 (2014). 